\title{
Worker Commitment not to Compete with the Employer Between Legislation and Judicial Precedent
}

\author{
Dr. Mohamed Khalil Yusuf Abu-Bakar \\ Assistant Professor and Deputy Dean of Faculty of Law, Al Zaytoonah Jordan University of Jordan
}

\begin{abstract}
The general rule that is "pacta sunt servanda" in Latin which means "Contract is the judge between contractors", and that each party to the contract has the right to agreement with the other party in the development of conditions that consent to them, and they have agreed that the conditions will not be void and be in accordance with the law and that they are not contrary to the Constitution, especially employment contracts, as of this contract that arranges obligations on both the employer and the worker, in which both parties could agree on the non-competition clause on the basis of article (818) and (819) of the Jordanian civil Code, but this agreement is considered a restriction on the worker freedom and collides with Article (23) of the Jordanian Constitution, Article (23) of the Universal Declaration of human rights and Article (4) of the Jordanian labor law.Therefore, when applying this agreement, it must to be taken into account that it is a restriction on the worker freedom, also it is an exceptional rule set for the legitimate interest of the employer, based on the condition that it will not restrict the worker freedom and it will not refrain the worker rights from work as a result of this condition; in return worker should be compensated in some conditions and the court should have a role in the agreement and its interpretation restrictively to the worker interest, so we can limit the spread of unemployment, since many professions, trades and industries are not considered hard to obtain secrets, due to the advancement in sciense and technology, and the easy ways to get it.
\end{abstract}

Keywords: obligation, legislation, employment, court, agreement

DOI: $10.7176 / \mathrm{JLPG} / 87-10$

Publication date:July $31^{\text {st }} 2019$

\section{Introduction:}

Work contract is an approved and binding for two sides, that rises legal obligations on both parties of the contract, the general rule state that the contract is the law that govern the contractors relations, Not contrary to public law \& order, also that contract conditions are not terms of compliance or violation of the Constitution, except what may arrange a conditions for a worker rights better than what is prescribed by the law.

One of these commitments that can be contained in the work-contract is worker obligation not to compete with the employer after the expiry of his work contract. It is stipulated in the Jordanian civil and labor laws obligation. Although Article 23 of the Jordanian Constitution and Article 23 of the Universal Declaration of Human Rights stipulates respect for the worker freedom to work, as a manifestation of individual freedom; however, this commitment and conflict of laws requires organising the labor laws to preserves employer interests and worker freedom and interests, to deal together not in contrary to the Constitution and the Declaration Universal human rights, and to create a balance between the two parties to preserve the interests of both worker and employer.

Jordanian legislator explicitly stipulated in the Jordanian civil law on the condition of worker commitment not to compete with the employer in articles 818 and 819 of the Civil Code.

The Jordanian labor law paragraph (b) of Article 19 of the Jordanian labor law. This condition raised conflict because such commitment forms as a constraint on the worker freedom, and article (4) of the Jordanian Labor Law that stated: "Shall be considered void every clause in the contract or agreement, whether concluded before or after this law in which any worker waives under any of the rights given to him by this law"1.

Stating a condition or a rule on the worker according to Jordanian Civil law that forbid him from competing or participating in a similar work after contract expiry, is considered restriction of the worker freedom, in addition to include a sort of financial penalty, raises a lot of questions, which are stated below:

1. To what extent the text of Articles 818, 819 are constitutional within Jordanian civil law, and to what extent of contradiction of these articles with Article 23 of the Jordanian Constitution and Article 23 of the Universal Declaration of Human Rights, which provide workers' rights \& freedom.

2. What is contained in articles 818 and 819 of the Civil Code is considered an exceptional restriction on the worker freedom and is also considered terms of submissiveness.

3. These texts conflict of these articles with Article 4/b of the Jordanian labor law, which consider it void every clause in the contract or agreement, whether concluded before or after this law waives

\footnotetext{
${ }^{1}$ Article (4) of Jordan labor law.
} 
4.

Worker under for any of the rights giving to him by this law.

This condition, which is set in work contract that prevent worker from working in the same profession, or work, or his craft, or his certificate is considered unconstitutional, because how could the worker live if it becomes prohibited for him to work in certain period of time in same craft or work or certificate or profession, and how he can secure a decent living for himself.

5. In the light of the technological development and the information revolution, there is not very much trade secrets, or industrial secrets, or others. since the world had become a small village, therefore anyone can get any information in light of information revolution.

6. this condition was set in law because of employer concerns and fear, which is not existing as it was before, since trade secrets and unfair competition found useless, because of scientific progress and technological revolution, this condition is not an important requirement at the present time. and If this condition is applied in place, time and type of work, then employer may expand his concerns, to a point that the worker will be without a job for a long time, and if he worked in the same field, which he agreed to oblige himself not to compete, then the worker, the weaker party does not have the amount that he should pay to the employer for compensation, even if employer suffered a loss as a result of the economic recession, which he could pass it back to the worker.

7. One of the problems in this commitment is how to prevent a worker who has a specialized degrees in scientific fields, whether in medicine or engineering, or pharmacy, or chemicals, or programming, from working with his certificate, which is considered the maximum restricted condition concerning the workers' rights and violation of his competence in his work, which is a clear violation of Article 23 of the Jordanian Constitution and Article 23 of the Universal Declaration of human rights and in contravention of paragraph (b) of Article (4) of the Jordanian labor law.

8. The introduction of competition condition causes conflict to the worker social condition, the denial of his right to compete which may deprive him from his rights in his natural career and profession, it is common that worker will accept this condition because of his need to work.

9.

10. This requirement raises a legal conflict of interests between the worker and the employer, it is not permissible that the worker is deprived to exercise his profession, or he will be facing an experience resulting from his work when leaving to work with other employer in the same field. the other conflict, is that this condition is considered by law as pressure on the worker in his work, which is considered as a condition of compliance, if the worker is still working with his employer as a result of a condition that forces him to stay in with the employer.

The importance of this research that this condition in the Jordanian civil law contrasts with paragraph (24) of Article (4) of the Jordanian Labor Law, and Article 23 of the Jordanian Constitution and Article 23 of the Universal Declaration of Human Rights, and must be interpreted in what is the benefit of the worker and in a very shallow interpretation.

The decisions of the Cassation Court in Jordan contradicted about this condition and has raised a lot of questions that we had mentioned among the problems in this research, since it addresses a controversy subject for employer, worker, judges as well as lawyers.

I used the analytical method for the laws and the comparative method, based on clear and specific idea introduced by it about the subject and the appropriate approach, in order to highlight subject elements and address it properly.

This research consisted of Introduction and two chapters.

Chapter One: which explained the extent of worker commitment of not competing with his ex-employer, and related conditions of the commitment after the termination of the employment contract.

First topic: the extent of worker's commitment on the not to compete-concept, its legitimacy when there is a contract between the worker and the employer.

The second topic: the terms of non-competition:

Chapter II: The effects of non-competition agreement and its legal nature

First topic: the effects of the non-competition agreement.

Second topic: the legal nature of worker's commitment not to compete

Finally was the conclusion and recommendations

There are in fact a number of difficulties encountered in the preparation of this research stands in the forefront the lack of modern legal references.

The plan

Chapter I: the extent of worker commitment not to compete with the employer's

First topic: the extent of worker's commitment on the not to compete-concept, its legitimacy when there is a contract between the worker and the employer.

Second topic: the terms of non-competition: 
Chapter II: The effects of non-competition agreement and its legal nature

First topic: the effects of the non-competition agreement.

Second topic: the legal nature of worker's commitment not to compete

\section{Chapter One}

The extent of worker commitment not to compete

with his employer and its conditions

One of the law arranged commitments that worker is not allowed to compete with employer in the duration of valid working contract, so worker is forbidden to work after the end of working hours for his own or for another person in order not to compete with his employer, taking into account the principle of good faith in the implementation of the labor contract, for example to work in his spare time with another employer competing with his employer, which is a fundamental commitment to entail a breach of the obligation to terminate the employment contract, without compensation or notice.

Employer may include in the employment contract a condition which prevents the worker from competing with him after contract expiry. Since it is up to the worker freedom to compete with his former employer, and that the obligation of preventing the worker to compete with his former employer as a result because of worker is familiarity with his employers secrets, whether worker is working in the same line of business such as industrial projects or he became more acquainted with the clients, beside the knowledge he formed regarding the technical aspects of work. Therefore employer may impose on the worker to refrain from competing upon the expiry of work contract.

our concern is the employment contract between the worker and the employer, in which the worker is obliged not to compete after the end of his employment contract.

Chapter One

this chapter is divided into two sections; the first section dealt with the issue of worker commitment not to compete, while the second section addressed the terms of non-competition.

The first section

What is it worker's commitment not to compete

The obligation not to compete is often shown in the employment contract and in cases where the employer feared the worker might compete with him after the termination of the employment relationship between them, because worker by work virtue might be aware of the employer secrets regardless of its types or importance, or build relationships with his employer customers, or gain the experience in other areas such as software or banking secrets.

However, this restriction is considered a serious issue on the trade and worker freedom, which threatens the worker means of livelihood, making this condition a mean of pressure on the worker to stay in work, and a large waste of worker freedom, that push to arising question here, how true is this condition after the expiration of the work contract?, whether this condition is true if stated in the contract of employment? And whether the worker is required to work in a job that is rival to his advantage, or to work privately through work or engaged in a work of another employer after the termination of the employment contract?.

Has the legislature in Jordanian law set the legal provisions regulating this requirement? And whether this condition is right? Weather the legislator had organised it and allowed its conditions, as to harmonise worker and employer interests? Is it considered a breach of confidentiality if the secrets became public and known among other people? Do the worker need to remain committed not to divulge secrets?

The non-competition clause in which the worker is committed to the employer, is based on the principles of good faith in the implementation of the contract, and that the contract is the law of the contractors; so worker will keep work secrets, whatever these secrets are, since work nature could reveal many of these secrets, weather identified customers of the employer or industrial secrets, trade secrets or receiving hands-on experience in some industries, or computer programs.

considering that such actions are confidential to the employer or to be confidential information or that there will be subtle at work seen by the worker to affect the employer if it is revealed or disclosed by the worker after the end of his employment contract.

Technical and skilled practices represent in fact an economic value, since they need high skills and efforts, so "from legal point view it is considered money morally"1.

The work setup technical knowhow is also considered a secret, because of its setup, machineries, work flow, production mechanism even storage mechanism component, anything in the work that the managers wish to hide from their competitors is considered business, beside any skill that the worker gain during his work is also

\footnotetext{
${ }^{1}$ Dr. Salahedeen Abdulateef Alnahy, The brief In industrial and commercial property, Amman Jordan, Alforqan publishing house, first edition, 1983, page 321.
} 
considered a secret"1.

We can also add computer software and banking secrets, in addition to other types of occupations that experience worker can be generated by the experience he get through practicing with the employer such as Goldsmith and precious stones. Which the worker gain experience through his work with the employer.

As well as software and computer programs, since the employer provide staff training sessions on these programs paying out huge amounts of money, especially if the training is held out of the country.

But to what extent the non-competition clause in the employment contract is legal?

Jordanian legislator stated in $\operatorname{article}^{2}(818)$ of the Civil Code, paragraph (1) "if the worker is in a position that allow him to view the secrets of work and knowledge of already established clients, then both worker and employer may mutually agree that worker could not compete or participate in the work rivaled after the end of his Contract".

Reference to this text, this condition is true and legitimate in accordance with the Jordanian Civil Code ${ }^{3}$, but to what extent it is legitimate in relation to Article $23^{4}$ of the Jordanian Constitution and Article $23^{5}$ of the Universal Declaration of Human Rights and Article (4) of Jordanian labor law.

And Article (6) ${ }^{6}$ and (27) of the International Covenant on Economic, Social and Cultural Rights.

Is there a contradiction between the text contained in the Civil Code, and the Jordanian Labor Law Article (4), and articles (23) of the Constitution, (23) of the Universal Declaration of Human Rights, Article (6) and (7) of the Covenant on Economic Rights (ICESCR) and social and cultural? is the applying of the text mentioned in Article (818) of the Jordanian Civil Code, and these conditions are considered compliance conditions? And when this compliance require judge interferes to amend or cancel it?

Article (818) of the Jordanian Civil Code, have identified the conditions that could make this rule applicable in the contract, or this condition will be considered invalid by law according to the Constitution and article (4) of the Jordanian Labor Law, and the International Declaration of Human Rights. In addition to that, it is considered a compliance condition and worker may challenge it by labor law which is set to protect worker interests and eliminate unemployment.

Therefore, the adherence of article (818) of the Civil Code, and applying the condition on the worker not to compete without making sure that this condition is set for special purposes, and not set as a compliance condition or for the intention of not allowing the worker from working in a similar work.

For example, i consider the setting of a long period of time to sustain the worker from joining a similar job, or setting up a huge sum of money as a penalty on the worker, or even setting up an area zone is considered exploiting of the worker needs, and forcing the worker not to leave work.

It is left to the judge to determine whether this condition is contrary, in terms of restriction of this condition in terms of time, place, and type of work, whether initiated this agreed actually to the interests of the employer legitimate requirement, as well as the agreed escrow value in case of agreement breach.

And whether the worker could not find a job if he does agreed and executed this condition, and who will compensate the worker during this period for refraining from work, then there must be a trade-off between workers and employers interests when this condition is applied.

Since this agreed upon condition, worker may not be able to work, which lead to increase the unemployment rate, beside he might have no other source of income, therefore the employer need to compensate the worker for the duration of unemployment period due to his refraining from work.

Since many of considered work secrets had as a result of technological advancement became not secret anymore. As well as establishments clients, and even some of the trade secrets, or training courses in the areas of computer programming, or handicrafts such as goldsmith or precious stones, also the training courses for the workers, we could say here that many of the so called work secrets are no more secrets now and could be

\footnotetext{
${ }^{1}$ Dr. Salahedeen Abdulateef Alnahy, (mentioned above), page 331.

${ }^{2}$ article (818) of Jordan Civil Law no. 34 for the year 1976. (If the worker is practicing a work that allow him to see the work secrets and knowledge of established clients, then worker and employer may mutually agree on the inadmissibility of worker to compete or join another work to compete against the former employer after the expiry of the contract. the agreement will be valid if it is restricted by time, location \& type of work, that is necessary and needed to protect the legitimate rights of the employer.

${ }^{3}$ Article (819) of the Jordanian Civil Law No. 42 of 1976, which stated that if both parties agreed that worker is committed to pay exaggerated fines in the event of breaching the non-competition with a view to forcing him to stay with the employer then this condition is invalid.

${ }^{4}$ Article 23 of the Jordanian Constitution, "work is a right for all citizens and the State shall provide opportunities for directing the national economy and developing it".

${ }^{5}$ article no. 23 of the international declaration of human rights stated that; "Everyone has the right to work and freedom of work choice in favorable and justified conditions and have the right to be protected against unemployment.

${ }^{6}$ were article (6) of the international covenant for the economical, social and cultural rights recognises the worker right to work.
} 
accessible easily due to technological advances.

In addition to the fact that when the worker leave his work this will open the doors to legitimate competition, and there is no harm to the employer.

It is considered void to interfere on the worker freedom to work and his choice of profession, in addition, Leaving the employer to control the worker on the basis of Article (818) of the Civil Code, it is a serious restriction on the worker freedom worker in the exercise of work. Since there must be a legitimate interest of the employer to put a condition in the employment contract for non-rival at work, although this condition may also lead to put restrictions on the freedom of the worker and trade, and its considered a violation of the worker individual freedom. And this condition is related to public order being since it contradict with the legal texts that have been developed for work freedom, to ensure workers' rights, to eliminate unemployment, and this is supported by the constitutions and international conventions.

Jordanian High court has supported that in its decision No. 1120/2014 Dated 09/23/2014 that (The requirement came general and absolute against the spirit of article(818) text of the Civil Code and against the spirit of Article 23 text of the Constitution and also Article (4/ b) of the Labour Code"1.

It was the Court of Appeal duty to address the terms of the contract between the parties of the claim, and to impose its control over the appealed decision.

As for the decisions that considered this condition invalid, providing ban from the competition if it comes open and not restricted, and weather the prevention is set for a reasonable period or not, it is a matter of logic for the judge to consider, based on the circumstances surrounding work, (Tunisia Court in primary rule no. 39131 dated 10131/2005 adopted the following: (when it considered that the inclusion of non-competition clause without restricting standards that will protect the interests of the worker is contrary to the provisions of the Constitution and the Universal Charter of human rights and the international Convention of the international Labor Organisation No. 122).

((and since the prevention of the worker from working in the territory of the Republic for a period of five years would deny his right to work within the constitution preamble, the Universal Charter of Human Rights dismissal (23) and the International Convention no. 122) $)^{2}$.

But the question that arises here, should we leave to the worker the right to work and compete with the employer to the general rules without stating these rules? And without being bound by the text of Article (818)? Is the general rules covering employer's interest in the non-competitive labor for his employer?

On the grounds that the workers freedom to work and freedom of competition, freedom invoked in his new job to the secrets of his ex-employer, or rely on his ex-employer customers, or compete with his ex-employer in the same location, or take advantage of the his ex-employer work secrets, and the training courses obtained and paid to train him, or workmanship secrets conveyed by the employer to the worker.

To answer this question; once the work contract ends without stating this condition in it, then worker is totally free to work, and there is no provision in the law or in the general rules that entitle the employer to refer to worker regarding any damages on the basis of labor law or civil law or contractual liability.

Because worker stance will be more powerful than the employer in reference to constitution, labor law and the Universal Declaration of Human Rights on work freedom, and in this case the worker degrades of responsibility in this situation.

In this case, $i$ see that if the ex-employer was harmed by the worker competition, then an estimated amount of compensation should be set against the worker without prejudice, since the basics in this issue is to prevent the worker from doing such action, and if the worker refused to refrain from that, then employer has the right to claim a reasonable compensation suitable to the extent of the damage.

In the case of worker's failure to stop competing against his ex-employer, i suggest that the court should control the worker to lock himself from competing with his ex-employer for a period agreed upon, and should rule that employer pay monthly wages to worker. So worker can make a living from this remuneration, because he is left without a work, which leads to unemployment and a violation of the very basics human rights to work.

How else can I prevent worker from a particular job while he is only able to work according to his experience, during which he had improved the quality or employer actions during his work with the him, and when applying the non-competition clause, and refrained from work, and when the worker comply to this condition, then worker has the right to claim compensation for this period which he will spend without work, or he have the right to collect the difference in payment between working in a non-competitive work.

The Second Topic

The Non-Competition Terms

The articles $(818,819)$ of the Jordanian Civil Code ${ }^{3}$ organised worker non- competition commitment with the

\footnotetext{
${ }^{1}$ Jordanian High court decision no. 1120/2014 dated 23/9/2014

${ }^{2}$ Khadija Zeyadeh, a research (Worker commitment not to compete with employer, Donya Al-Watan, 2013.

${ }^{3}$ articles $(818,819)$ in the Jordan Civil law.
} 
employer after the expiry of the contract, and not during the work period; since there is no need for a legal text regarding worker competition with the employer during his work with him.

This is because of the obligations placed upon worker to be fully dedicated to his work and to preserve work secrets based on the principle of good intentions which is imposed by the contract on both parties relationship.

There is no text in the Jordanian labor law refraining the worker from competing with his employer after ending of the employment contract, but in Jordanian Civil Code stated in paragraph 1 of (Article 818) : "if the worker position allows him an access to work secrets and knowledge of established clients, it may be mutually agreed between employer and worker that worker may not compete with the employer or participate in a competitive work rivalled after the expiry of the contract, also paragraph 818/2 stated that the agreement will not be acceptable unless it is constrained by time, place and type of work to the extent necessary to protect the legitimate interests of the employer .

while article (819) of the Jordan Civil Code stated that: If both parties agreed to make the worker pay an exaggerated compensation in the case of breaching of competition intent, to force him to stay with the employer then the condition is invalid.

The same case is mentioned in the Egyptian Civil Code $(686.687)^{1}$, which stated the restriction on the worker freedom to work after the end of the employment contract, provided that the non-competition agreement, since this condition frequent in work contracts related to chemical industries, trading brokers, and high ranked bankers. $^{2}$

Although this condition in the employment contract is considered a restriction on worker freedom of action or trade, but this issue could not be neglected since it means restraining employer's rights, and not acknowledging such conditions to conserve both interests of worker and employer.

But these legal texts did not set standards for these conditions mentioned by the laws, and left it for judge opinion and the experienced people to assess these conditions to state whether these conditions are valid or invalid, including the data provided these cases to implement these conditions, whether the worker started his independent work or employed by a competitor of his ex-employer who encouraged him to leave his ex-job and offered him higher salary.

And I will explain these conditions as follows:

The First condition: the protection of employer legitimate interests:

The competition preventing clause has been set to protect the employer legitimate interests from the worker, because of worker access to employer secrets and to customer's database; it is a legitimate interest to maintain employer rights. So when the judge is reviewing any lawsuit against a worker he need to consider this condition in terms of the existence of employer legitimate interest, in regard to the importance of employers fears and concerns in protecting his interests.

If there is no interest to employer in this agreement, then there is no fear for the employer, and that the legitimate interest is serious and not fake.

So paragraph $19 / \mathrm{b}$ of the Jordanian labor law stated that: "The worker should conserve the employer industrial and commercial work secrets and not to disclose them in any way, even after the expiry of the contract of employment as required by the agreement or as known in the market general customs"3.

When non-competition clause is stated in the labor contract this presupposes the existence of a legitimate interest of the employer to justify this requirement, and the judge looking at the hearing of the case, should first and foremost check if this employer condition is serious and legitimate or not.

The benefits of the employer is achieved when job assigned to the worker allow him to access the employer secrets and to know the established clients $^{4}$, this required condition is set because employer may fear worker competing against him after the expiry of the contract by contacting his customers, or by taking advantage of work secrets revealed to him during his work, and then to compete with the employer by disclosing secrets or contacting his customers.

"Since this later commitment, does not prevent the worker from exploiting for his own account" 5 . If it is determined that the worker can't or don't have access to employer' secrets to view it, even if the employer was absent from work, then this condition is void ${ }^{6}$.

\footnotetext{
${ }^{1}$ articles $(687,686)$ of the Egyptian Civil law

${ }^{2}$ consultant Mohamad Azmy Albakry, Explaining the New Labor Law - Mahmoud publishing and distribution house, No year, page. 470

${ }^{3}$ paragraphe B/19 of Jordan Labor law no. (8) for the year 1996 and its amendments.

${ }^{4}$ article (818/1) of the Jordan civil law: "If the worker job allow him to see work secrets and knowledge of established clients, then both parties may mutually agree on worker not to compete with the employer or participate in the work rivalled after the expiry of the contract"

${ }^{5}$ dr. Mohamad Labeeb Shunab, explaining the Labor law, Arab Renaissance Publishing House, 1996 . p. 159

${ }^{6}$ dr. Mohamad Labeeb Shunab, et. al. p. 159
} 
Any clause contained in the contract that is not based on the employer interests, which might be linked to worker knowledge of work secrets and know how, and contacting employer customers by the worker; this condition is considered null and void.

The second condition: compromising not to discuss:

In order to approve worker and employer agreement on the non-competition clause in the employment contract, there must be approval by both the employee and the worker on this condition, including all other conditions, even after the expiration of the labor contract, therefore contract need to include an agreement on non-competition", and this does not require special formula in the agreement"1.

The contract must indicate clearly the well of both parties to prevent the worker from competing with the employer, in the same work practiced during his duty, or to compete with the employer by dealing with employer clients, by specifying time, place, and type of work, as well as the non-competition clause with the employer, so that he does not work when with another employer or company or to participate with another company, or to practice work of his own in a rival project to his employer.

It does not matter what type of condition is stated in the agreement, this condition is seen "as a restriction on the freedom of worker and trade" 2 .

When disagreement occurred between the worker and the employer, solution need to be interpreted to side with worker therefore decision need to be interpreted restrictively.

The question that arises here, if the contract did not include non-competition or worker freedom worker to work after contract expiry, then it is legal for worker to join any project, or company or start his own business.

But if the non-competition clause was included in the contract, stating that worker can't work for a rival project, or participate in a competitive project, or joining another competitor employer. If, however, excluded any of these conditions, then it is permitted for a worker to work with the others, because the interpretation must be strictly construed in favor of the worker, and should not make this condition openly absolute for the rest of other types of businesses to compete with others.

The third condition: the eligibility of worker for contracting:

Jordanian civil law requires that the person who will sign the work contract need to be in legal adult age in the time of contract signing, so worker can understands what the conditions which has been agreed in the employment contract when hired, but the question that arises here, Can a guardian agree to this condition as to whether the worker has not reached adulthood, and answer to this question, that this condition is false.

for the worker, who has not attained maturity age, or is not yet fully competent to contracting, he may stick to the invalidity of this condition in any case. "The agreement which requires no competition clause is considered invalid being revoked in the worker interest"3.

The legislator wisdom in stressing the requirement of full acceptance of the eligibility requirement, due the seriousness of this condition on the worker freedom that is related to public order, and even to the extent of worker awareness of his commitments and aware of the results related to this agreement). On this basis, the conclusion of a contract by a minor is valid, but the condition is invalid.

The fourth condition: The Worker is assigned to a work that allows him to know the employer clients and have access to work secrets.

This text was explicit in paragraph 1/article (818) of the Civil Code (if the worker duties allowed him to view work secrets and knowledge of established clients then employer and worker may mutually agree that the second will not compete or participate in the work revealed to him after the contract end with the first) ${ }^{4}$.

The Jordanian legislator stipulated that to apply this requirement, if the worker and the work entrusted to him, allows him access to the secrets of work and to know enterprise customers. Because entrusted worker knowledge of employer work with regard to clients and work secrets is the points that make the employer fear them from competition after the expiration workers employment contract.

But if the worker duty did not allow him to know the secrets of the work or the employer's clients, then worker is exempted of non-competition, and the employer does have serious interest to justify restricting the freedom of the worker, since this condition and this situation is forcing the worker to stay in his work and pressure him not to leave work, and this is a restriction on the freedom of worker and trade.

And so did the Egyptian legislature who considered that the clause which provides the prevention of competition shall be void, if the nature of the worker does not allow him access the secrets of the employer or his agents.

"According to the above, if the work carried on by the worker does not allow him to have access to employer secrets or to contact the organization customers, then the worker in this case is considered a foreigner

\footnotetext{
${ }^{1}$ dr. Mohamad Labeeb Shunab, et. al. p. 147

2 dr. Mohamad Labeeb Shunab, et. al. p. 141

3 dr. Mohamad Labeeb Shunab, et. al. p. 142

${ }^{4}$ paragraph $818 / 1$ of Jordanian Civil Law.
} 
to his employer, which means that it is permissible to worker to compete with his employer after leaving his work. Therefore the employer interest is not serious or not legitimate, and thus it invalidates the non-competition clause"1.

It is up to the judge to assess the extent in which the worker can access or view the secrets of his employer and his clients, and if this clause is highly serious to protect the employer interests and secrets.

The fifth condition: prevention to be relatively not absolutely:

Paragraph (2) of Article (818) of the Jordanian Civil Code stated that: "The agreement is not considered acceptable unless it is restricted by time, place and type of work to the necessary extent to protect the legitimate interests of the employer"2

Jordanian legislator limited the prohibition clause of the act to protect the interests of the employer, by determining the terms of time, location and type of work.

The ban regarding the time:

The Jordanian legislator stipulated the validity of this condition to be limited to certain period of time, it may not be an absolute ban, the period of time must be specific and a reasonable, it may not be absolute or eternal duration. Otherwise counting this clause is void, and considered a restriction on the freedom of trade and worker, and that it is up to the judge to decide whether the period is reasonable or not, or it is considered a restriction on the worker freedom.

"it is up to the judge to assess whether the specified period in the agreement is reasonable, in which relative prevention is achieved in terms of time in the light of the circumstances surrounding the work"3.

The issue of whether the ban period is reasonable or not, it is an issue decided by the judge, in light of the circumstances surrounding the work, which "was adopted by the court in Tunis primary rule number (39131) Dated 13.1.2005 when it considered the unrestricted non-competition clause without complying with the standards of protecting the worker interests is contrary to the provisions of the Constitution, the Universal Charter of human rights and the international Convention of the international Labour Organization No. 122 on work policy) ${ }^{4}$. This means that the restriction in time should be relative.

But the question that arises here, in the case of preventing the employer to the worker a reasonable period of time has been implemented by the worker, and the worker left without work throughout this period, who will compensate the worker for this period, as the Jordanian legislator did not expose in the case of worker's not working for specific and proportional time regarding the place and type of work, I see that the worker may claim compensation if these proceedings brought non-competition. Because it does not make sense that the worker stays without exercising work or activity for a certain period, because the public interest, pushes toward the need to compensate the worker for the time that he is refrained from work, since we need to deal based on the business principle of what is most useful to the worker - so the explanation in this is what is more useful to the worker situation, since worker may not be deprived of the benefits he gained by his experience, without harming the interests of the employer.

The prohibition in terms of the place:

The employer has a legitimate interest in preventing the worker - based on the cases mentioned earlier - in the place (location) where the employer is practicing his work, for example, where the prevention reach a location that the employer activities is not extended to, or the prevention is extended to all over the region, or the state, and in the case that the restriction is covering the country in general, then this requirement shall be void.

"The location need to be identified and restricted in area, and shall not be open or not limited"5.

"The ban must be limited to a particular place (location) and it is often linked to the area within the extended activities reached by the employer, since there is no legitimate interest of the employer to prevent the worker from his rival in a place that he is not active in. ${ }^{6}$

We find that absolute depriving of the worker from competing with employer is impermissible activity, if the later activities does not cover the area that the worker is active, because the ban does not protect the legitimate interests of the employer.

therefore we found that the Jordan Cassation Court has issued its decision No. 1120/2014 which included

\footnotetext{
${ }^{1}$ Dr. Tawfeeq Hasan Faraj, Labour Law, University Publishing house, p. 188, Beirut, 1986.

2 paragraph (2/818) of Jordan Civil Law.

${ }^{3}$ Dr. Hasan Kerah, the principles of Labor law, Knowledge Establishment, Alksanderia, edition 2, published 1960, p. 253.

4 "to prevent the prosecutor from working in full territory of the Republic for a period of five years it would deny him the right to work within the constitution, the Universal Charter of Human Rights dismissal (23) and the International Convention for work number (122) concerning the policy used, and published in the Official Gazette of the Tunisian Republic and ratified by Law Number (44) 1965 dated 12/12/1965, which in turn referred to Chapter 23 of the Universal Declaration of human rights referred to above "(published research on the Internet, Home World, date of 03.28.2013, prepared by Khadija Zeyadah, "Binding the worker from competing with the employer".

${ }^{5}$ advisor Mohamad Azmy Albakry, the New Labour law, et. al., p. 474.

${ }^{6}$ Dr. Hasan Kerah, et al, page 252.
} 
(that exception and limitation provided in Article 818 of the Jordanian civil law intended to protect the interests of the employer, so this restriction is necessary to the extent of protecting the legitimate interests of the employer only) (And since the condition in which the contents of the contract between the parties of this lawsuit came absolute and general as stated in article 18, which is contrary to text of Article 818 of the Civil Code, therefore contradicts with Article 23 of the Constitution and Article 4/b of the Labor Code) ${ }^{1}$

While another decision sided with employer's legitimate interests even if his work reached beyond the region, and beyond the type of work that the worker had occupied during his service period, and since the worker was an executive or director of the company and its activities extends to other countries or regions and he was exposed to company's customers and its secrets, and since the company was dealing with computer services and internet, providing networking and communication to clients, therefore the employer has the right to prevent the worker from work not based on physical location only but also based on the activities locations, even if the employer activities are set beyond the boundaries of the region", that was the Jordanian Court of Cassation decision no. 1299/2014 dated 7/8/20142.

The percentage of competition clause in terms of work type:

Prohibition of competition clause cannot be achieved if it is not specified and should also be limited to the worker duties linked to employer line of business, and also prohibition must be specified to the necessary extent to protect the employer legitimate rights.

If the ban took place on absolute manner, then non-competition clause is invalid, noting that pressuring the worker by restricting working prevention according to type of work, may restrain worker freedom, especially when the worker knows only this type of work."

(the Prevention of competition must be relative with regard to work type, so worker is restrained only from doing the same items that his ex-employer does, or the work related to employer trade or craft) ${ }^{3}$

with regard to to works and businesses that do not conflict with the employer profession or craft, if practiced by the worker is not considered a breach or compete with the employer, since employer does not have a legitimate interest in depriving the worker from this work. Therefore, absolute agreement in terms of work type is considered invalid, because it is considered a restriction on worker freedom to exercise his right to work.

Sixth condition: the non-competition agreement should not be combined with exaggerated penal:

Article $819^{4}$ of the Jordanian Civil Code stated that: "If the parties agreed that the worker should pay an exaggerated amount of money in case of breach in the refraining from competition clause, in an intention to force him to stay with the employer, then the condition is invalid".

Jordanian lawmaker set up a condition of agreement validity in addition to the conditions mentioned previously, that non-competition clause should not be combined with exaggerated penal, since the exaggeration condition is intended to force the worker to stay in business, then this condition is invalid.

It is up to the trial judge to consider this requirement in terms of validity, whether the condition was restricting the worker freedom to join other work if he leave work or force him to stay in his work with the employer, therefore, the judge need to check first whether the penalty clause is an exaggerated intent of the employer to force the worker to stay with him; in this case, the judge may issue a decision considering this condition in which the employer intentionally force the worker to stay working for him is invalid, and if the condition is considered invalid then all other clauses are considered invalid too, because this clause was not stated to protect the legitimate rights of the employer.

But the question that arises here, what if this clause meant really to protect the interest of the employer and was not exaggerated? then can the Judge rule to reduce the value of the compensation to the extent that is equal to the employers damage value.

We respond to this question, we view article (364/2) of the Jordanian Civil Code, which states that: "The Court in all cases at the request of one of the parties to amend this Agreement, to make the appreciation equal to the damage, and any agreement that will be considered void if it is contrary to that." 5

And it is the judge task in such condition to determine first whether the condition is exaggerated - to issue his decision that the condition is not valid with intention to force the worker to stay at work.

\footnotetext{
${ }^{1}$ Jordan Cassation Court legal decision no. 1120/2014 dated 23/9/2014.

2 Jordan Cassation Court legal decision no. 1299/2014 dated 08/7/2014. ( its is clear facts of the case and the evidence presented in papers that the worker breached his obligation with the plaintiff discrimination against them when he founded with other companies in the same area in which the Prosecutor operates on 8/2 / 2007, which is the Bedayah telecommunications company and information technology, which is registered as a company with limited liability and he was appointed in on 10/2/2007 in his capacity as Vice President of directors and general manager of the company, company services included computer Services and internet, providing communications networks services and electronic programming, the claimant has the right to claim for compensation).

${ }^{3}$ Dr. Hasan Kerah, Et al. p. 254.

${ }^{4}$ article 819 of Jordanian Civil Law no. 42 for the year 1976.

${ }^{5}$ paragraph 2 of article 364 of Jordan civil law
} 
The second task is when the parties objected on the value of this condition when they think it is not equal to the damage value, then the court have the right to modify the agreement, to make the appreciation equal the damage, according to the supportive evidence provided by each party.

"The Egyptian legislator has considered this requirement invalid, therefore this invalidity is applied also on the agreement of competition prevention"1

Chapter II

The Effects of the non-competition agreement

and its legal Nature

The First Topic:

non-competition agreement effects

The Second Topic:

the legal nature for worker commitment not to compete

Chapter II

The Effects

of the non-competition clause

and its Legal Nature

This chapter will deal with the non-competition clause effects and its legal nature; divided into two sections; the first dealt with the impact of non-competition clause on the worker and the extent of labor mandatory to this requirement, if the employer set the non-competition clause on the worker contract upon termination of the contract, so worker will not be able to work with another company or to be a partner in the company, or selfemployed or stated the requirement in absolute terms. And to what extent the worker has the right to claim compensation in case he was prevented from working with others at the expiration of the contract? and when the worker loses his rights in front of the employer in this condition?

There are namely two cases; first, in the event of contract termination by the employer, or when the employer breach the contract, these are the reasons for contract terminate, in this case the employer loses the right to adhere to the condition or the agreement.

I also addressed the impact of non-competition clause on the employer, when the worker breach the agreement, which is considered the employer right in demanding physical implementation by stopping the worker from the competition and claim compensation for the harm he suffered in accordance with the agreed terms of the work agreement, as well as the closure of the worker place of work.

And also i dealt with the impact of non-competition clause on others, such as the new employer whom the worker had signed in a new contract with, whether to partner or to work with him, and if the new employer knows or does not know about the worker non-competition clause in the old agreement with his previous employer, Which might lead to make the previous employer claiming compensation from the new employer.

It also dealt with the impact of non-competition clause, whether it will even follow related people of the worker, in another word, could the non-competition clause be transferred to the related people of the worker or not.

While in the second section, I dealt with the legal nature of the non-competition clause as to whether this requirement was stated in the work contract; the nature of the breach; the claim of not to compete in accordance with the contract obligations, and whether the employer can refer to the worker if did not want a condition in the contract in accordance with the general rules and worker obligations.

What is the obligation nature of the new employer, and the basis of such obligations, if he employed this worker, or partnered with him while knowing about the non-competition clause, and compensation claim and the bases of his responsibilities, in such case the rules of tort should be applied.

What is the fate of the employment contract between the worker and the new employer, and whether noncompetition clause is of particular and exceptional nature violates the principle of freedom of action, freedom of trade and economy, it also affect the worker future, and violates the constitutions, international treaties and conventions, and does it make the worker entitled to compensation for preventing him from working, All these issues will be discussed in two sections.

The first section will discuss the effects of non-competition clause, while the second section will discuss the nature of the non-competition clause.

The first topic

The impact of non-competition agreement

If an agreement is held between the employer and the worker on the non-competition clause, and it was correct according to Articles 818 and 819 of Jordan Civil Code, Then the agreement is valid and binding to worker, accordingly the worker is committed not to compete with the employer, and is prohibited from competing with the employer.

${ }^{1}$ Dr. Mohamad Shabeeb, et al, p. 145 
in this section we will deal with the following issues:

First: the impact of non-competition clause on the worker.

Second: the impact of non-competition clause on the employer.

Third: the impact of non-competition clause on others.

Fourth: the impact of non-competition clause on particular successor.

I will address these topics in detail as follows:

First: the impact of non-competition clause on the worker:

The worker is obliged and bonded to the non-competition clause if the employment agreement was valid and in accordance with Articles 818 and 819 of Jordanian Civil Code, which means that worker is committed to refrain from work, whether this work is limited to the current employer, or is meant working with another employer, or working refrained from even being a partner or an owner of his own work. but if the employer limited the worker from working with his competitors only, then worker right to work on his own business is not forbidden, including being a partner in the company, All the above is liable after the worker meets the conditions that were agreed upon after the expiration of the contract, so when the worker breach the Agreement, he will be held responsible before the employer.

But there are two cases in which the employer is not permitted to hold to the on non-competition clause in the work agreement, although the Jordanian legislator did not refer to these cases in the Jordanian civil law, were the worker has the right not to be obliged in these two cases to the non-competition agreement, and the worker has the right to compete against his employer, and these two cases are:

1. If the employer Terminated the contract or refused to renew without any negative action of cause from worker that justify such action, then employer has no right to stick to the contract, (therefore the employer has no right to ask for non-competition clause from the worker when the contract termination is caused by the employer, in such case the worker is degraded from the noncompetition clause, weather employer was wrong in this termination or not $)^{1}$.

if the contract was not restricted to period term, and the employer terminated it on his own well, then it is not permissible for the employer to adhere to the non-competition clause on the agreement, whether the employer has the legitimate justifications for it, or the worker job was terminated arbitrarily, as long as it was not the wrong doing from the worker that justified the contract termination.

2. If the employer committed an action that justifies the worker termination of the employment contract, then in this case worker is allowed to leave his work without because of employer breeching, as stated in Article 29 of the Jordanian Labor Law ${ }^{2}$, in which the worker have the right to leave work in cases (although the worker is the one who left willingly, but the reason for this is a mistake made by the employer, therefore law penalised the employer by making him lose his right to withholding to the non-competition clause in the work contract"3.

when the worker does not commit himself to non-competition clause of the the work agreement, then worker is obliged in return to compensate the employer for damages and violation of his obligations toward the employer.

I think, asking the worker for compensation is often not feasible, because worker is not fully capable to meet compensation terms, and not able to pay, but worker would be able to shut down the shop or institution and so the competition is over.

But the question that arises here: does the worker deserve compensation for the period he refrain from work when he commits himself not to compete? Also, if the worker is fit only for the work he is forbidden to do, can he ask for compensation?

I see that when the worker sign a non-competition work contract with his employer, he should clearly state the compensation value to cover the refraining from work period. This way worker can find compensation for the period of refraining from work.

The same issue was mentioned in Article 953 of the preliminary draft of the Egyptian civil law which stated that such condition of non-competition could be legal when "the contract grant the worker compensation on this contract that contain restriction on worker freedom suitable to the length of this restriction"4.

This view was supported by; "binding the worker to do his work as a reason to employer's obligation to pay him fairly, if the worker did not get a return for his commitment to the non-competition obligations including the constraint imposed on his freedom, then this commitment is without reason and is therefore null and void"5.

Therefore worker need to be compensated weather in the start of the work agreement or even after the

\footnotetext{
${ }^{1}$ dr. Hasan Kerah, et al. p. 256

2 article 29 of Jordan labor law no. 8 for the year 1996 and its modifications (this article stated the cases that allow the worker to leave his work without notifications and they are 8 cases.

${ }^{3}$ Dr. Mohamad Labeeb Shunab, Explaining Work Contract, Alnahda Alarabiyah publishing house, eygpt, 1966, p. 146.

${ }^{4}$ legal consultant Mohamad Azmy Albakry, the New Labor Law, Mhamoud publishing house, 2nd. edition, p. 480.

${ }^{5}$ dr. Jamal Zaki, the Brief in Labor Law, Aletihad library and publishers, p. 140.
} 
expiration of his labor contract, to refrain him from competition, as we find it necessary to compensate the worker for this limitation imposed on his freedom, since the worker may be fit only to work what he is forbidden to do so.

Second: the impact of non-competition clause on the employer:

If the conditions set forth in the context of articles 818 and 819 of the Jordanian civil law were available, which is the non-competition clause, then the agreement would be valid and binding to the worker. and when he breach it, then employer have the right to request the following from the worker:-

1. Execution in kind.,

2. Request compensation for the damages done to him.

3. Claim compensations from the new employer.

1- Execution in kind: if the worker breached the agreement of non-competition, by launching his own business, then employer can immediately request; execution in kind, in which the worker is forbidden from working on his own, or with other company, or even as a partner in a company; by filing an urgent request to the judge of urgent matters and introduce indemnity guarantee against any losses, if it is proved the agreement was legitimate and in accordance with articles 818 and $819^{1}$ and it was proved that there is a legitimate interest of the employer, then the employer may request the closure of the shop established by the worker.

2. The employer can file a lawsuit to claim compensation for material and moral damages based on the conditions set forth in articles 818 and 819 , and if the agreement includes a penalty clause and was not overstated, then it is the employer right to claim the agreed condition, while if there was not any penalties condition in the contract or that parties did not set up or agreed on a certain amount, it is permissible for an employer to demand compensation for material and moral damages caused, based on his loses and the gains missed according to contractual liability.

3. Ex-employer can request compensation from the new employer if it turns out that the new employer already knew about this non-competition issue between the worker and his old employer, therefore "its considered tort from the new employer side"2. All that without prejudice to the contract between the new employer and the worker; because the old employer claims to terminate the work contract between the worker of the on the new employer, is legal issue between the two employers.

Third: the impact of non-competition clause on others:-

The new employer is obliged to compensate the old employer if he knew about the working agreement between the first employer and the worker on non-competition and he had contracted with the worker regardless, or partnered with him to establish a new company, were usually in many cases the new employer always try to convince the worker to leave the old work and join him, although he is very well aware of the non-competition clause between the worker and his employer, or in another way, the new employer ask the worker to join him with new project or work with him, these actions will negatively harm the first employer and this entitled him to ask for compensation from the new employer accordingly, or for the lost profit based on tort, the old employer need to prove that the new employer is aware of the non-competition clause in the worker contract with the old employer.

Fourth: the impact of non-competition clause for the Particular successor:

The right of the employer on the non-competition clause turns to the particular successor after his death, "as stated in article 207 of the Jordanian Civil Law"3, That "If the contract established personal rights related to something that had transferred to the successors, then the rights related are also transferred to the successors, when the successors know about the issue at the time of transfer".

it is clear from the text of the law that the not-to-compete agreement is considered rights to the work place, factory or the establishment, therefore it these rights are still binding and transferred to the successors and it become part of the new work place.

so the basic rule state that the successors inherits the rights and obligations of Predecessor arising from a contract if it was essential part of it, and they knew about it, "and the worker will be obliged not to compete in the project and not only towards the employer"4.

The second topic

Legal nature of the non-competition clause

I will address here the legal nature of the non-competition clause between the worker and the employer, if it was mentioned or not mentioned on work contract, and if the worker is obliged not to compete? beside discussing the nature of the new employer responsibility and the consequences related.

\footnotetext{
${ }^{1}$ articles 818 and 819 in Jordanian Civil Law

2 hasan Keada, et. al., p. 255.

3 article 207 of Jordan Civil Law no. 42 for the year 1976.

${ }^{4}$ Legal Consultant Mohamad Azmy Al-Bakri, the New Labor Law, Mahmoud publishing and distribution house, Egypt, p. 480.
} 
The nature of the worker's commitment to the non-competition clause in work contract is contractual responsibility, as Jordan civil law has mentioned it in Articles 818 and 819, when the work contract include this condition, then it is binding to the worker to execute it according to the agreed terms, also he is responsible in the event of breaching and will be held legally responsible, therefore worker will be required to compensate the employer; either according to the financial security agreement, which was between the worker and the employer, and with what the judge will rule if the the financial penalty was exaggerated, which is subject to the the intention of the employer, it was was to force the worker to stay with him and to consider this condition is void, and whether the compensation was equal to the value of the damage, and regarding the amount agreed upon, the judge can decrease or increase it according to the damage estimated by the judge based on Article 364 of the civil Code ${ }^{1}$.

But the question that arises here, if the agreement did not include a certain amount as compensation to the employer, then what are the principles that the judge will relay on to estimate the compensation amount? and what is the nature of responsibility that the judge will apply in this case?

If the employment contract and the agreement on non-competition did not include a certain compensation amount, then the judge has to rule against the worker in accordance with the contractual responsibility for material and moral damages, the employer can request to stop the execution, or ask for execution in kind, by preventing the worker from continuing the work, or close his work place, and all that because of the damages resulted on the owners work and for what he had lost in profit.

But if the new employer knew already about the worker agreement with his old employer that includes a a non-competition clause and still instigated the worker to leave work, or opened a new business with the worker, then responsibility for the new employer is tort, then the old employer need to proof that the new employer was aware of the existence of an agreement between old employer and the worker that include a non-competition clause.

also the old employer should prove the mistake and the damages and the causal relationship to tort, to prove the material and moral damage caused to him giving him the right to claim compensation.

The question that arises here, is it legal for the old employer to file a legal complain asking the worker not to compete with him, if their work contract did not include an a non-competition clause?

If the employment contract did not contain a non-competition clause, then worker is not obliged to be committed, and since the legislature has stated the existence of non-competition clause as a condition, then the bond that connects the worker with the employer is associated with the contract and not the law, and therefore worker is not bonded to not to compete with the old employer.

Another question arises here, is the non-competition clause falls in the interest of the worker or the employer?

The non-competition clause falls in the interest of the employer, and therefore he is entitled to waive it. and therefore the employer takes the burden of proving the offence, as well as all matters related to it, including the prove of contract existence, the proof of material and moral damages, and the introduction of material facts and evidences including the testimony of witnesses.

As the Jordanian legislator did not set stipulated that the agreement must be written, therefore in order to know the legal nature of the non-competition agreement, it is necessary to explain it in favour of the workers in the narrowest possible interpretation ${ }^{2}$. Since article 240 of the Jordanian Civil Code, paragraph 1 explains the uncertainty to the debtor's best interest. However it should not be interpreted ambiguous phrases in adhesion contracts detrimental to the interests of the obedient party ${ }^{3}$. "if there is a doubt about a particular phrase in the contract, and the question arises as to whether the term includes an obligation on the worker not to compete, or allow it, then it must be interpreted as allowing the worker to compete ${ }^{4}$.

And that the non-competition clause is of exceptional nature, it has been developed for the benefit of the employer, and as a restriction on the worker freedom and the freedom of trade and industry, despite the fact that a lot of industries and professions have become very well known, thanks to technological advances, and it became available to everyone to the extent of seeing, practicing and applying it. In addition to an ease of accessing information needed to manage projects; particularly with the existence of computer information systems applications, industrial inventions, other businesses and professions, trades and industrial computer programs.

So this restriction should not violates the constitutions and international conventions that guarantee the

\footnotetext{
${ }^{1}$ article 364 of Jordan Civil law.

2 Decision of the Court of Cassation: "taken advantage of Article 818 of the Civil Code that the exception change stated in Article 23 of the Constitution and Article 4 of the Labour Code is intended to interest the employer protection and required to be explained in the narrowest possible way and not be expanded to its absolute as stated in Resolution No. 1120/2014 dated 23/9/2014.

${ }^{3}$ article 240 of Jordan civil law.

${ }^{4}$ Mohamad Labeeb Shunab, et al., p. 158.
} 
workers rights and his freedom of trade and industry, therefore worker need to be compensated in all cases, because the unemployment may had a role in forcing the worker acceptance of this condition. and I think because of the increased growth of unemployment rate, this condition may be a compliance requirement, In many cases the worker is forced to accept it for the purposes of getting work.

If the worker accepted this condition, then the court and the judge play a major role in search for the nature of this Agreement; whether it is accepted by the worker because he does not find other work; or because the employer forced the worker to accept it to force him not leave work; or the fact that there is a legitimate interest of the employer.

Therefore, the agreement conditions must be interpreted in the narrowest way possible in favour of the worker, so court can intervene in the amount of compensation to protect worker from the unemployment, and to see that compensation is paid for the worker who might not be able to work because of his implementation of this agreement.

Findings and recommendations

In this research I dealt with workers commitment not to compete with the employer between legislation and the provisions of the judiciary in the Jordanian law, which were discussed in the first chapter that included two sections; I discussed in the first the worker commitment in the non-competition clause along with the concept and legitimacy of this commitment, while in the second section I dealt the conditions of non-competition; the second chapter was also divided into two sections, in the first one I continued the discussion of terms and conditions of non-competition, while I dealt with the nature of non-competition clause in the second section.

I also reached a conclusion that the non-competition clause could not be applied in all professions, businesses, industries or trades, and that their is a need to apply Articles 818 and 819 of the Jordanian Civil Code, according to the interest of the employer in the narrowest possible ways, in terms of time, place and type of work as well as the penalty clause.

And I also concluded that this exceptional condition may not be used as a restriction on worker work freedom, which is considered incompatible with the Constitution, the human rights charter and international conventions, and that the judge must intervene to explain this agreement narrowly in favor of the worker without elaboration, and he should rule for an adequate estimation of compensation if conditions where approved accordingly.

Although the Jordanian legislator had mentioned this agreement in the Jordanian civil law, but that the agreement sometimes collide with the Jordanian Constitution and the Labor Law Article 4, the Universal Declaration of Human Rights Article 23 and international conventions.

However, there are some recommendations and suggestions which I hope will be taken into account, namely:

1- an addition to Articles 818 and 819 of the Jordanian Civil Code, so the non-competition clause must be coupled with the worker's right to be paid under this condition to compensate him for refraining from working for a certain period of time mentioned in the agreement.

2- an addition to the text of Articles 818 and 819 of the Jordanian Civil Code, and to protect the workers interests; if he is able only to do the work he is declined to do so he will not compete with his ex-employer, then he has the right to claim compensation from the employer for the period in which the worker locked up from the same work, otherwise how can the worker manage his life without income for himself, this condition is considered a restriction on the worker freedom, and incompatible with the Constitution and the Universal declaration of Human rights and international conventions.

3- To add a text to articles 818 and 819 of the Jordan Civil code stating the right of the employer to claim implementation in kind to stop the worker from work or the closure of his new business.

4- Setting and developing of standards to be considered by the judges in the applying of these provisions so as to be interpreted as narrow as possible for the benefit of the worker.

5- addressing of the professions that can be subject to competition, that provide a legitimate interest of the employer.

6- when proceedings in court, it must be taken under consideration that this clause is an exceptional condition that form restriction on the worker freedom, and court need to judge in favour of the workers interests, in balance with the Constitution and international covenants; and the legitimate interest of the employer, by making a balance between the two.

7- Not to over-compensate the worker while applying Article 364 of the Civil Code, or to reduce or increase the compensation.

8- The non-competition clause is considered null and void if it showed or indicated that the intention of the employer was directed towards forcing the worker not to leave work or that it overstated the amount of compensation that need to be paid by the worker to employer, which make this condition entirely void.

9- The termination of the contract by the employer or by the worker because the employer, is considered degeneration of worker obligations to the non-competition condition.

10- The agreement on the non-competition condition must be in writing for the purpose of proof as stated in 
Article 818 of the Jordanian Civil Code.

11- The non-completion condition need to be stated clearly in the Jordanian labor law, as the legislator did not stated it in the Jordanian labor law despite the amendments which took place on this law.

12- The court should take into consideration that there are professions, crafts and industries, that had became known to the public because of the technological and scientific evolution, the easy access to it and work that has been publicly known by many people, and it is no more a secret to anyone.

This research is considered the outcome of a modest effort which dealt with the non-competition condition with the employer in the Jordanian legislation, the provisions of the judiciary, and reported some of the findings and recommendations, hoping that I was lucky enough in my try to link the law current stand, with the judges' rulings on the new circumstances that were not taken into account when developing these laws.

finally. I ask God to make my work useful and give me every success I need.

\section{References}

First: Books:

1. Dr. Tawfiq Hassan Faraj, Labour Law, University House Printing and Publishing, Beirut, 1986.

2. Dr. Hassan Kedah, the principles of labor law, knowledge facility of Alexandria,1960.

3. Dr. Salahuddin Abdul Latif Al-Nahi, the brief in the industrial and commercial property, Jordan, Amman, Dar Al-Furqan, 1983.

4. Dr. Mohamed Labib Shanab, Explaining the labor law, Dar Arab Renaissance, Cairo,1966.

5. Dr. Mahmoud Jamal Al-Din Zaki, The brief in labor law, library and Press Union in Zagazig, Cairo.

6. Judge Mohamed Azmi Al-Bakri, Explaining the new labor law, Mahmoud Publishing and Distribution house, Egypt.

Second: The laws, regulations and instructions:

7. Jordanian Constitution

8. Jordanian Civil Law No. 43 of 1976

9. Jordanian Labour Law and its amendments No. 8 of 1996.

Third: The judicial authorities:

10. Jordanian Court of Cassation rulings, the Jordanian Bar Association.

Fourth: the agreements:

11. Universal Declaration of Human Rights.

12. International Covenant on Economic, Social and Cultural Rights.

Fifth: Publications:

13. Khadija Zeyadah, an internet published research, Worker commitment not to compete with the employer's, Dina Alwatan, 2013. 